\title{
KINERJA PERAWAT DI INSTALASI RAWAT INAP RSUD SAWAHLUNTO
}

\author{
Desrison $^{1)}$, Sri Langgeng Ratnasari ${ }^{2)}$ \\ ${ }^{1}$ Program Studi Magister Manajemen, Universitas Riau Kepulauan \\ email: desrison.rsud@ gmail.com \\ ${ }^{2}$ Program Studi Magister Manajemen, Universitas Riau Kepulauan \\ email: sarisucahyo@yahoo.com
}

\begin{abstract}
ABSTRAK
Perawat sebagai bagian integral dari layanan medis, memilki andil besar untuk memith layanan medis di rumah sakit. Perawat di rumah sakit merupakan hal utama layanan medis, karena sumber daya manusia yang paling banyak mengandung dan paling interaktif dengan klien terus menerus dan seimbang untuk memberikan layanan medis komprehensif dan reaksi profesional. Penelitian ini bertujuan untuk mengetahui faktor faktor yang berpengaruh terhadap kinerja perawat. Penelitian dilakukan pada instalasi pemasangan RSUD, Sawah Lunto. Rancangan penelitian yang digunakan adalah cross sectional, proses data dan analisis dengan menggunakan program komputerisasi SPSS untuk window versi 11.0 dengan Chi Square Test. Populasi penelitian adalah semua perawat yang bertugas di ruang istirahat RSUD, Sawah Lunto dalam operasi bedah, ruang anak, dan layanan bidan, jumlahnya 56 orang, dan seluruh populasi menjadi sampel. Dari hasil penelitian didapatkan $51,8 \%$ model kerja dari perawat seperti biasanya bukan yang terbaik. Hasil statistik menunjukkan bahwa pengaruh antara motivasi, gaji, dan gaya kepemimpinan, di sisi hin pendidikan berpengaruh tidak signifikan dengan kinerja. Menurut pengamatan tersebut, perawat lebih banyak menambahkan motivasi untuk bekerja, petugas di rumah sakit harus menarik insentif perawat dan petugas kepala menambahkan lebih banyak aktivitas dan pengendalian kepada perawat yang bekerja.
\end{abstract}

\section{Kata kunci: Motivasi, Gaji, Gaya Kepemimpinan, Pendidikan, Kinerja Perawat}

\section{PENDAHULUAN}

$\begin{array}{cr}\text { Tujuan pembangunan } & \text { bidang } \\ \text { kesehatan } & \text { sebagaimana } \\ \text { tertuang }\end{array}$

dalam undang-undang kesehatan No.

23 Tahun 1992 adalah untuk meningkatkan kesadaran, kemampuan hidup sehat bagi setiap orang agar terwujud derajat kesehatan masyarakat yang optimal Untuk mewujudkan tujuan tersebut perlu adanya upaya kesehatan yang baik dan menyeluruh, terpadu dan berkesinambungan oleh sumber daya tenaga kesehatan. Tenaga perawatan merupakan salah satu sumber daya manusia bidang kesehatan yang melalui ilmunya akan mendukung tercapainya tujuan pembangunan bidang kesehatan.

Tenaga keperawatan Rumah Sakit adalah ujung tombak pelayanan kesehatan, karena merupakan sumber daya manusia yang berjumlah terbesar dan paling banyak berinteraksi dengan klien terus 


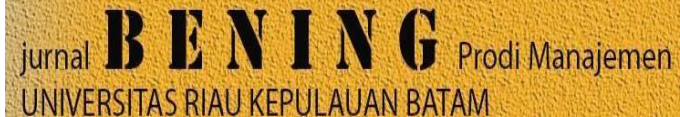

menerus dan berkesinambungan

untuk memberikan asuhan

keperawatan yang komprehensif dan professional.

Pelayanan keperawatan adalah pelayanan professional yang merupakan integral dari pelayanan kesehatan, didasarkan pada ilmu dan kiat keperawatan, berbentuk pelayanan bio-psiko, sosio-spiritual yang komprehensif ditujukan kepada individu, keluarga, kelompok dan masyarakat, baik sehat maupun sakit yang mencakup seluruh proses kehidupan Pelayanan keperawatan di numah sakit merupakan faktor penentu bagi mutu pelayanan dan cirra rumah sakit di mata pasien, keluarganya dan masyarakat.Untuk menjaga mutu tersebut dibutuhkan tenaga keperawatan yang professional dan berkinerja tinggiKinerja adalah penampilan hasil karya personel baik kualitas maupun kuantitas dalam suatu organisasiKinerja dapat merupakan penampilan individu maupun kelompok kerja personel. Menurut Gibson (2007) ada 3 (tiga) kelompok variabel yang mempenganuhi perilaku kerja dan kinerja yaitu: variabel individu, variabel psikologis dan variabel organisasi Variabel individu terdiri dari kemampuan dan keterampilan (mental, fisik), latar belakang (keluarga, tingkat sosial, pengalaman), demografis (umur, asat usul jenis kelamin).Variabel psikologis terdiri dari persepsi, sikap, kepribadian, belajar, dan motivasi.Sedangkan variabel organisasi terdiri dari sumber daya, kepemimpinan, imbalan, struktur dan desain pekerjaan. Sedangkan menurut Robin (2014) terdapat 3
Volume 5 No. 2 Tahun 2018

(tiga faktor utama yang mempenganuhi kinerja, yaitu: (1) kemampuan (fisik, mental, pengetahuan dan keterampilan), (2) Motivasi, (3) Kesempatan. Kemudian penelitian yang dilakukan Harris (2011), menyimpulkan bahwa ketidakpuasan pasien terhadap pelayanan perawat adalah disebabkan oleh ketidakteraturan control perawat terhadap pasiennya, keterampilan dan wibawa perawat yang kurang. Bentuk ketidakpuasan pasien dalam wujud rasa kecewa, kesal, tidak senang yang disebabkan oleh faktor kurang ramah kecepatan memberkan pelayanan, kurangnya fasilitas layanan.Perawat pelaksana adalah tenaga keperawatan yang diberi wewenang untuk melaksanakan asuhan keperawatan di ruang rawat.Di Negara maju untuk memenuhi tuntutan masyarakat terhadap pelayanan masyarakat serta pelayanan keperawatan, perawt pelaksana adalah perawat professional yang telah menyelesaikan pendidikan tinggi di Universitas.Di Indonedia menurut Hamid (2009) perawat pelaksana kualifikasi dan kemampuannya sangat terbatas, $88 \%$ tenaga keperawatan berpendidikan di bawah Diploma keperawatan.

Di dalam pelayanan keperawatan, yang berperan sebagai pemimpin lini pertama adalah kepala ruangan. Kepala ruangan merupakan manajer di suatu ruang rawat inap dan harus mampu mengkoordinir kegiatan melaui fungsi-fungsi manajemen yang menjadi tanggung jawabnya, agar perawat pelaksana dapat menjalankan tugas pelayanan keperawatan dengan baik.Tinggi 


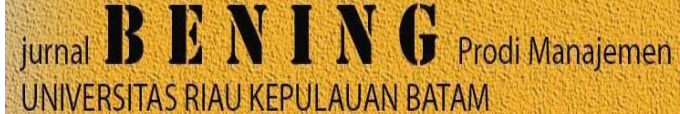

rendahnya mutu pelayanan

keperawantan di Rumah Sakit salah satunya ditentukan oleh kinerja perawat pelaksana dan kinerja kepala ruangan, jika kinerja kepala ruangan baik. Maka kinerja staffnya juga akan baik. Rumah sakit umum daerah (RSUD) Sawahlunto merupakan Rumah Sakit tpe C milik pemerintah daerah Sawahlunto dengan SK Menteri Kesehatan No. 481/Menkes/SK/V/1997, dengan 5 (lima) pelayanan pokok, yaitu: pelayanan administrasi dan manajemen, pelayanan medis, pelayanan keperawatan, pelayanan gawat darurat dan pelayanan rekam medic dengan kapasitas tempat tidur sebanyak 71 tempat tidur. Tenaga keperawatan berdasarkan Data Kepegawaian tahun 2004 jumlah tenaga kerja perawat di instalasi rawat inap sebanyak 56 orang, kecuali perawat yang menjadi kepala di ruang rawat inap. Distribusi tenaga keperawatan berdasarkan tingkat pendidikan adalah D3 keperawatan 32 orang, D3 kebidanan 3 orang, D1 kebidanan 8 orang dan SPK 13 orang.Menurunnya kinerja perawat berpengaruh terhadap jumlah BOR (bed occupancy rate) dan ALOS (average length of stay).Menurut sub bagian data dan informasi direktur jenderal pelayanan medic (2002), BOR dan ALOS merupakan indicator untuk menilai tingkat keberhasilan atau memberi gambaran tentang pelayanan di Rumah Sakit. Hasil survey awal peneliti, pada ruangan penyakit dalam dan ruangan bedah, dari 10 status pasien yang peneliii ambil secara acak, hanya 3 status format asuhan keperawatan yang terisi, berarti $70 \%$ tidak terisi.
Volume 5 No. 2 Tahun 2018

Hasil wawancara singkat penelii dengan 2 orang pasien yang telah selesai menjalani masa perawatan, ada keluhan dari pasien tentang pelayanan perawat yang bertugas di malam hari masih kurang (perawat kurang teratur dalam mengontrol pasien ke ruang rawat inap), perawat kurang ramah dalam berkomunikasi dengan pasien dalam memberikan pelayanan keperawatan. Wawancara dilakukan dengan hari yang sama terhadap 6 orang orang perawat yang sedang bertugas di nuangan penyakit dalam dan ruangan bedah, 4 orang perawat menyatakan kepala ruangan jarang memberikan pengarahan/penggerakkan terhadap perawat pelaksana di ruangan rawat inap. Sehubungan dengan permasalahan yang ada, peneliti ingin menelii beberapa faktor yang berhubungan dengan tingkat kinerja di instalasi rawat inap RSUD Sawahlunto.

\section{Tujuan Penelitian}

Menganalisis mengenai tingkat kinerja perawat dan faktorOfaktor apa saja yang berhubungan dengan tingkat kinerja perawat di instalasi rawat inap RSUD Sawahlunto.

\section{Tinjauan pustaka \\ Pengertian Kinerja}

$\begin{array}{cll}\text { Menurut Ilyas (2009) kinerja } & \\ & & \end{array}$ personel baik kuantitas maupun kualitas dalam suatu organisasi Menunut Prawirosentono (2011), kinerja adalah suatu hasil kerja yang dapat di capai oleh seseorang atau kelompok orang dalam organisasi sesuai dengan wewenang dan tanggung jawab masing-masing dalam rangka mencapai tujuan organisasi bersangkutan, secara legal 
tidak melanggar hokum dan sesuai dengan moral dan etika. Menunut Notoadmojo (1992), kinerja adalah status kemampuan yang di ukur berdasarkan pelaksanaan tugas sesuai uraian tugasnya. Kinerja menurut Fitpatrick adalah proses yang dilakukan dan hasil yang dicapai oleh suatu organisasi dalam menyediakan jasa pelayanan atau produk kepada pelanggan.

Berdasarkan pendapat di atas dapat disimpulkan bahwa kinerja

mempunyai hubungan erat dengan masalah produktivitas karena merupakan indicator dalam menentukan bagaimana usaha untuk mencapai tingkat produktiftas yang tinggi dalam suatu organisasi.

\section{Model Teori Kinerja}

Dalam organisasi ada sejumlah orang yang harus memainkan peranan sebagai pengikut.Hubungan antar individu dan kelompok dalam organisasi menghasilkan suatu harapan terhadap perilaku kerja individu. Ada tiga kelompok variabel yang mempenganuhi perilaku kerja dan kinerja, yaitu: variabel indovidu, variabel organisasi, dan variabel psikologis.

Menurut Gibson (2007), model teori kinerja dengan melakukan analisis terhadap sejumlah variabel yang mempengaruhi perilaku dan kinerja individu. Variabel individu dikelompokkan pada sub variabel kemampuan dan keterampilan, latar belakang dan demografis. Sub variabel kemampuan dan keterampilanmerupakan faktor utama yang mempenganuhi perilaku dan kinerja individu. Sub variabel demografis mempunyai hubungan baik tidak langsung pada perilaku dan kinerja individu. Variabel psikologis terdiri dari sub variabel persepsi, sikap, kepribadian, belajar dan motivasi Variabel ini menurut Gibson (2007), banyak dipenganuhi oleh keluarga, tingkat sosial, pengalaman kerja sebelumnya dan sub variabel demografis. Variabel psikologis seperti persepsi, sikap, kepribadian dan belajar merupakan hal yang kompleks dan sulit diukur.Variabel organisasi menunut Gibson (2007), berefek tidak langsung terhadap perilaku dan kinerja individu. Variabel organisasi terdiri dari sub variabel sumber daya, kepemimpinan, imbalan, struktur dan desain pekerjaan.

\section{Penilaian Kinerja}

\section{Definisi Penilaian Kinerja}

Penilaian kinerja adalah proses penilaian hasil karya personel dalam suatu organisasi melalui instrument penilaian kinerja. Pada hakekatnya penilaian kinerja merupakan suatu evaluasi terhadap kinerja personel dengan membandingkan dengan aturan yang ada. Menurut Carto (2014) penilaian kinerja adalah proses penelusuran kegiatan pribadi personel pada masa tertentu dan menilai hasil karya yang ditampilkan terhadap sasaran sistem manajemen. Menurut Hall (1986) penilaian kinerja adalah proses yang berkelanjutan untuk menilai kualitas kerja personel dan usaha untuk memperbaiki unjuk kerja personel dalam organisasi. Tenaga professional adalah sumber daya terbaik bagi suatu organisasi sehingga penilaian kinerjanya menjadi salah satu variabel yang penting bagi efektivitas organisasi Penilaian kinerja adalah proses 


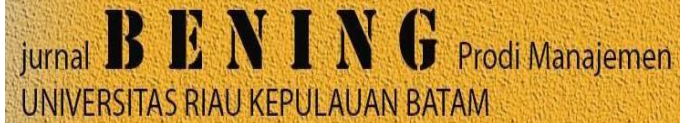

mengidentifikasi prestasi kerja

karyawan sehingga tujuan organisasi secara efektif dapat di capai. Kegiatan penilaian kinerja ini membantu pengambilan keputusan bagian personalia dan memberikan umpan balik kepada para personel tentang pelaksanaan kerja mereka.Penilaian kinerja mutlak harus dilakuakn untuk mengetahui kinerja yang dapat dicapai setiap karyawan.

Faktor-Faktor Yang Mempengaruhi Penilaian Kinerja

Pengamatan merupakan proses menilai dan menilik perilaku yang ditentukan oleh sistem pekerjaan. Ukuran yang dipakai untuk mengukur prestasi kerja seseorang personel dengan uraian pekerjaan yang telah ditetapkan oleh personel tersebut.Pengembangan, yang bertujuan untuk memotivasi personel mengatasi kekurangan dan mendorong yang bersangkutan untuk mengembangkan kemampuan dan potensi yang ada pada dirinya.

Tujuan Penilaian Kinerja

Penilaian kinerja pada dasarnya mempunyai dua tujuan, yaitu: Tujuan utama, (a) penilaian kemampuan personel merupakan tujuan yang mendasar dalam rangka penilaian personel secara individual yang dapat digunakan sebagai informasi untuk penilaian efektivitas manajemen sumber daya manusia (b) pengembangan personel sebagai informasi untuk pengambilan keputusan dalam pengembangan personel, seperti: promosi, mutasi, rotasi, terminasi, dan penyesuaian kompensasi; Tujuan Spesifik, yaitu: mengenai SDM yang perlu dilakukan pembinaan, menentukan kriteria
Volume 5 No. 2 Tahun 2018

tingkat pemberian kompensasi, memperoleh kualitas pelaksanaan pekerjaan, bahan perencanaan manajemen program SDM masa datang, memperoleh umpan balik atas hasil prestasi personel.

\section{Manfaat Penilaian Kinerja}

Handoko (1985) menyatakan ada

10 (sepuluh) manfaat penilaian kinerja, yaitu: perbaikan prestasi kerja, kesempatan kerja yang adil, kesalahan-kesalahan desain pekerjaan, ketidak akuratan informasi kebutuhan lathan dan pengembangan, perencanaan dan pengembangan karier, penyimpangan-penyimpangan proses staffing, penyusunan kompensasi, tantangan-tantangan eksternal, keputusan-keputusan penempatan (promosi, transfer, demosi).

Metode Penilaian Kinerja

Metode yang sering digunakan dalam penilaian kinerja menurut Ilyas (2009) adalah essay technique, skala peringkat, check list/daftar isian, field review method, metode kompensasi, wawancara.

Hal Yang Perlu Dinilai Pada Perawat Rumah Sakit

Hubungan dengan pasien, hubungan dengan rekan kerja, kemampuan professional, potensi untuk tumbuh dan kembang, sikap terhadap rumah sakit, kualitas personel.

\section{Kinerja Perawat}

Kinerja perawat dapat dithat dari kegiatan yang dilakukan dalam memberkan asuhan keperawatan yang terdiri dari pengkajian, diagnose keperawatan, perencanaan keperawatan, pelaksanaan keperawatan, evaluasi keperawatan, catatan keperawatan. 


\section{Uraian Tugas Perawat \\ Pelaksanaan Di Rumah Sakit}

Perawat pelaksana diruang rawat mempunyai uraian tugas sebagai berikut (Depkes RI). Memelihara kebersihan ruang rawat dan lingkungannya, menerima pasien baru sesuai prosedur dan ketentuan yang berlaku, memelhara peralatan keperawatan dan medis agar selalu dalam keadaan siap pakai, melakukan pengkajian keperawatan dan menentukan diagnose

keperawatan sesuai batas kewenangan, menyusun rencana keperawatan, sesuai dengan kemampuannya, melakukan tindakan keperawatan kepada pasien sesuai kebutuhan dan batas kemampuannya, melath pasien untuk melakukan lathan gerak, melakukan tindakan darurat kepada pasien sesuai protap yang berlaku, melaksanakan evaluasi tindakan keperawatan sesuai batas kemampuannya, mengobservasi kondisi pasien, berperan serta dengan anggota tim kesehatan dalam membahas kasus dan upaya meningkatkan mutu asuhan keperawatan, melaksanakan tugas rutin, mengkuti pertemuan berkala yang diadakan oleh kepala ruang rawat, meningkatkan pengetahuan dan keterampilan di bidang keperawatan antara hin melalui pertemuan ilmiah dan penataran atas in atasan, melakukan sistem pencatatan dan pelaporan asuhan keperawatan yang tepat dan benar sesuai standar asuhan keperawatan, melaksanakan serah terima tugas kepada petugas pengganti secara lisan maupun tertulis pada saat penggantian dinas, memberikan penyuluhan kesehatan pada pasien dan keluarganya sesuai keadaan dan kebutuhan pasien mengenai program diet, melath pasien menggunakan alat bantu yang dibutuhkan, melath pasien untuk melaksanakan tindakan keperawatan dirumah, dan menyiapkan pasien yang akan pulang.

\section{Pengertian Dan Uraian Tugas Kepala Ruangan}

Kepala nuangan adalah seorang tenaga keperawatan yang diberi tanggung jawab dan wewenang mengatur dan mengendalikan kegiatan pelayanan keperawatan atau posisi kunci dan keberhasilan pelayanan keperawatan di ruang inap, karena harus mengkoordinir seluruh kegiatan yang berlangsung diruang lingkup tanggung jawab. Uraian tugas kepala ruangan merupakan indikator untuk menilai kinerja kepala ruangan, meliputi: fungsi perencanaan, pengarahan, pengawasan.

\section{Standar Asuhan Keperawatan}

Standar asuhan keperawatan adalah pernyataan deskriptif dari tingkat pelaksanaan kerja yang diinginkan, sehingga kualitas terstruktur, proses dan hasilnya dapat dinilai, sebuah standar keperawatan merupakan pernyataan deskriptif kualitas pelayanan yang hanus diberikan kepada klien.Tujuan standar asuhan keperawatan menunut Gillies (1996) adalah meningkatkan kualitas asuhan keperawatan, mengurangi biaya perawatan, menghindari perawat berbuat kelalaian. Standar asuhan keperawatan sebagai pedoman dan dasar evaluasi pelaksanaan asuhan keperawatan, telah ditetapkan dengan surat keputusan menteri kesehatan RI 
No.

660/Menkes/SK/IX/2007,

dilengkapi surat edaran direktur Jenderal Pelayanan Medik No. 105/Yang.Med/RS. Umdik.RAW/88, tentang penerapan standar praktek keperawatan bagi perawat kesehatan di Rumah Sakit.

\section{Beberapa Faktor Yang Berhubungan Dengan Kinerja Motivasi}

Menurut Hasibuan (1996) adalah suatu kekuatan yang dihasilkan dari keinginan seseorang untuk memuaskan kebutuhannya.Kopelmen (1986) dalam Ilyas mengatakan, bahwa motivasi mempenganuhi kinerja. Pada penelirian Yanuar (1989) dalam Ilyas,menyimpulkan bahwa motivasi meningkatkan penggunaan waktu produktif personel. Motivasi merupakan hasil sejumlah proses yang bersifat intemal maupun eksternal bagi seorang individu yang menyebabkan timbulnya sikap antusias dan presistensi di dalam melaksanakan kegiatan-kegiatan tertentu. Pentingnya motivasi karena motivasi adalah yang menyebabkan menyalurkan dan mendukung perilaku manusia supaya mau bekerja giat mencapai hasil yang optimal.Motivasi pribadi untuk bertindak adalah hasil dari kekuatan diri sendiri atau kebutuhan, keinginan untuk berprestasi dan nilai insentif yang mekkat pada tujuan.

Imbalan

Mink dala Ilyas (2011) menyimpulkan bahwa imbalan merupakan salah satu komponen yang mendukung kinerja yang tinggi. Pada kondisi demikian karyawan akan bekerja keras dan tekun karena menghasilkan sesuatu yang diharapkan. Menark karyawan yang berkualitas bergabung dalam organisasi, mempertahankan karyawan agar tetap datang bekerja, meningkatkan kepuasan kerja dan memotivasi karyawan mencapai tingkat prestasi yang tinggi adalah sasaran utama program imbalan. Menunut Hasibuan (2011), insentif adalah daya perangsang yang diberikan kepada karyawan berdasarkan prestasi kerjanya agar karyawan terdorong untuk meningkatkan produktivitasnya. Faktor-faktor yang mendorong besarnya insentif adalah penawaran dan permintaan tenaga kerja, kemampuan dan kesediaan perusahaan, organisasi, produktivitas kerja karyawan peraturan pemerintah, biaya hidup, posisi jabatan karyawan, kondisi perekonomian nasional, pendidikan dan pengalaman, jenis dan sifat pekerjaan.Tujuan memberikan insentif berdasarkan petunjuk pelaksanaan pemberian penghargaan/insentif difingkungan DepKes RI adalah diharapkan meningkatkan kualitas dan prestasi kerja dan disiplin karyawan dan memberikan dorongan bagi karyawan untuk lebih meningkatkan produktivitas dan prestasi kerjanya.

Pendidikan

Menurut Likert dalam Gibson (1996) bahwa tingkat pendidikan yang lebih tinggi pada umumna menyebabkan orang hin mampu berusaha memberi posisi yang bertanggung jawab. Latar belakang pendidikan akan mempenganuhi motivasi kerja tenaga keperawatan. Menurut pendapat Clank dalam Raflita (2011), yang menyatakan 


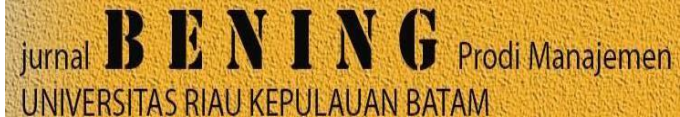

bahwa kemampuan interpersonal, intelektual dan teknikal seseorang sangat didasarkan kepada pendidikan formal. Menurut Ilyas (2009), bahwa penilaian diri sesorang sangat efektif dan efesien dilakukan untuk mengukur kinerja tenaga professional kesehatan yaitu dokter, dokter gigi dan perawat.

\section{Kepemimpinan}

Kepemimpinan adalah cara seseorang pemimpin mempenganuhi perilaku bawahan, agar mau bekerja sama dan bekerja secara secara produktif untuk mencapai tujuan organisasi Menunut pendapat Hasibuan (2011) mengemukakan bahwa kinerja karyawan banyak dipengaruhi oleh sikap pimpinan dan kepemimpinan. Menurut Grant dalam Timpe (1993) bahwa para manajer dan bawahan berbagi tanggung jawab dan keduanya aktif dalam membantu proses seperti komunikasi kepemimpinan dan kekuatan sosial Kepemimpinan adalah proses dua arah, satu pihak harus mengetahui cara memimpin dan pihak lain harus mengetahui cara mengikut.Menurut Gillies (1996) mengemukakan bahwa pengarahan dapat memungkinkan perawatan pasien lebih berkualitas.Sehubungan denga hal tersebut pengarahan difokuskan pada pelaksanaan pelayanan keperawatan, kebijakan dan standar asuhan keperawatan. Menurut pendapat Kron dan Gray (2007) dalam Reffita (2011), menyatakan bahwa pengawasan yang dilakukan kepala ruangan terhadap perawat pelaksana saat bekerja bertujuan untuk pengawasan dan inspeksi pada asuhan keperawatan
Volume 5 No. 2 Tahun 2018

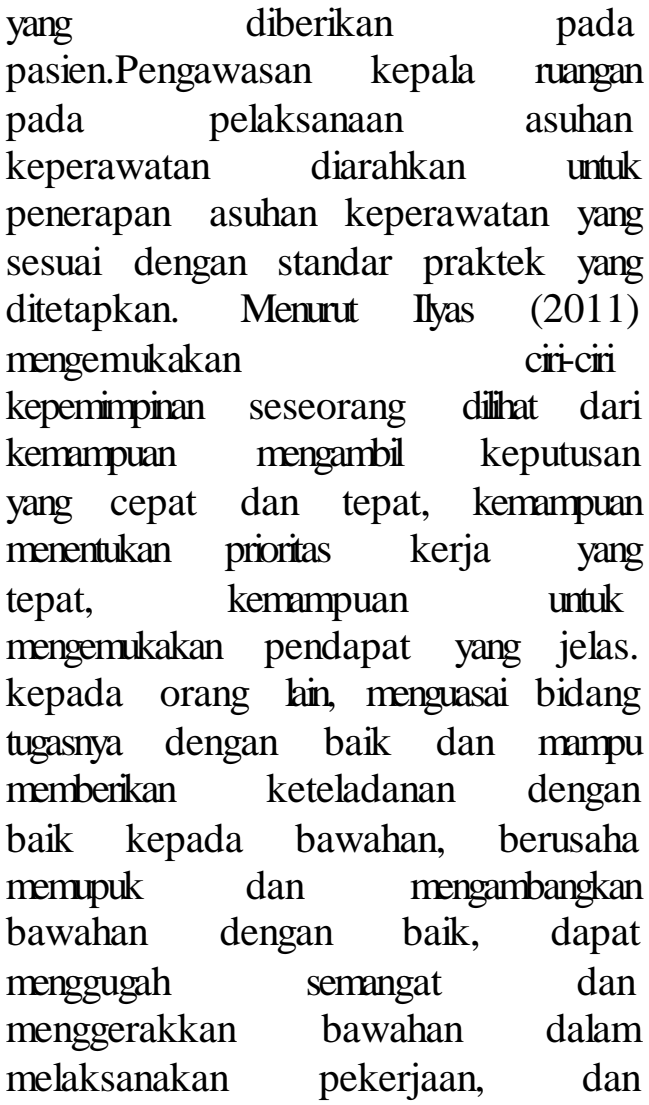
bersedia mempertimbangkan saransaran bawahan dan memperhatikan nasib serta mendukung bawahan untuk maju. Definisi kepemimpinan yang dikemukakan Gibson (2007) menyatakan bahwa kepemimpinan melibatkan penggunaan penganuh dan menyangkut pentingnya proses komunikasi karena kejelasan dan ketepatan komunikasi mempenganuhi perilaku dan prestasi pengikut. Kualitas pemimpin organisasi kesehatan sangat menentukan terhadap tingkat kinerja organisasi pelayanan kesehatan itu sendiri.

\section{Kerangka Konsep}

Berdasarkan tinjauan pustaka di atas diasumsikan kerangka konsep tentang beberapa faktor yang berhubungan dengan tingkat kinerja perawat di instalasi rawat inap RSUD Sawahlunto mangacu pada 
teori Gibson (2007). Menurut Gibson (2007) menyampaikan secara teori ada tiga kelompok variabel yang mempengaruhi perilaku kerja dan kinerja, yaitu: variabel individu, variabel organisasi, variabel psikologis. Dalam penulisan ini yang diteliti adalahvariabel individu, yaitu: tingkat pendidikan. Variabel organisasi, yaitu: kepemimpinan dan imbalan. Variabel psikologi, yaitu: motivasi.Variabel individu, variabel organisasi, dan variabel psikologi yang berkaitan dengan perawat yang bekerja di instalasi rawat inap merupakan variabel independen dalam penelitian iniSecara sistematis

\section{METODE PENELITIAN}

\section{Desain Penelitian}

Penelitian ini merupakan penelitian kuantitatif yang bersifat deskriptif analitik dengan pendekatan Cross Sectional Study, untuk melihat hubungan antara variabel dependen dan variabel independen dalam periode waktu yang sama.

\section{Lokasi dan Waktu Penelitian}

Lokasi penelitian dilaksanakan di Instalasi Rawat Inap RSUD Sawahlunto yang meliputi: bangsal penyakit dalam, bedah, kebidanan dan kandungan dan bangsal anak. Waktu penelitian dilaksanakan mulai dari bulan Januari sampai bulan Juli 2015.

\section{Populasi dan Sampel}

Populasi dalam penelitian ini adalah selunuh perawat pelaksana yang bertugas sebagai tenaga keperawatan di instalasi rawat inap RSUD Sawahlunto yang berjumlah 56 orang.Selunuh populasi di jadikan responden dalam penelitian ini dengan kriteria sebagai berikut.
Kriteria Inklusi: bersedia untuk menjadi responden penelitian, berada ditempat pada saat penelitian.

Kriteria Eksklusi: sedang sakit, cutillibur atau sedang pendidikan/tugas belajar.

\section{Variabel Penelitian}

Variabel indipenden adalah tingkat motivasi, tingkat imbalan, tingkat pendidikan, dan tingkat kepemimpinan Variabel dependen adalah tingkat kinerja perawat.

Instrumen Penelitian

Instrumen penelitian yang digunakan untuk mendapatkan informasi dalam penelitian ini adalah angket dengan menyebarkan pertanyaan-pertanyaan singkat yang diberikan kepada responden dan observasi yang dipandu check list yang berisikan uraian tugas perawat diruangan rawat inap RSUD Sawahlunto.

\section{Pengumpulan Data}

Data dikumpukan dengan mengedarkan angket kepada responden sesuai dengan jumlah sampel yang diinginkan, kemudian dikumpulkan, dicek untuk selanjutnya dilakukan pengolahan data. Sedangkan pengamatan dipandu dengan check list yang dibantu 2 orang teman yang telah penulis lath untuk menghindarkan terjadinya bias. Setiap ruangan dilakukan observasi selama tiga hari, diharapkan setiap perawat dalam shift jaga dapat terobservasi.

\section{Pengumpulan Data}

Menyunting data, dilakukan untuk memerksa adanya kesalahan atau kekurangan kelengkapan data yang isi oleh responden.Hal ini dikerjakan dengan memeriksa tiap lembar angket pada waktu menerima dari 


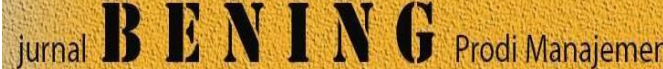
UNIVERSITAS RIAU KEPULAUAN BATAM

pengumpul data.Memasukkan data, seluruh data telah dikode dengan bantuan komputer.Membersihkan data, dilakukan bila terdapat kesalahan dalam memasukkan data.

Analisis Data

Analisis data dilakukan untuk mengolah data ke dalam bentuk yang lebih mudah di baca dengan bantuan komputer program SPSS for window versi 11, kemudian diinterprestasikan untuk menguji secara statistic kebenaran hipotesa yang telah ditetapkan. Analisis data dilakukan dalam 2 tahap: (1) analisis Univariat, dilakukan untuk mengetahui distribusi frekuensi atau proporsi masing-masing variabel yang ditelii, baik variabel dependen maupun variabel independen; (2) analisis Bivariat, bertujuan untuk melihat hubungan variabel independen dengan variabel dependen. Uji yang digunakan pada bivariate ini adalah Chi Square dengan menggunakan derajat kepercayaan $95 \%$.

\section{Definisi Operasional}

1. Motivasi adalah keinginan kecenderungan perawat dalam melayani pasien di ruang rawat inap.

2. Imbalan adalah penilaian responden terhadap insentif / jasa pelayanan dalam bentuk uang yang diterima responden diluar gaji resmi setiap bulan.

3. Pendidikan adalah tingkat pendidikan formal keperawatan terakhir responden.

4. Kepemimpinan adalah penilaian responden tentang upaya kemampuan kepala ruangan menggunakan seluruh tenaga pelaksana perawatan secara
Volume 5 No. 2 Tahun 2018

maksimal untuk melaksanakan tugas-tugas yang ada.

5. Kinerja perawat adalah hasil kegiatan yang dilakukan perawat ruangan dalam bentuk pendokumentasian dan memberikan asuhan keperawatan kepada pasien berdasarkan SOP keperawatan selama bertugas.

HASIL DAN PEMBAHASAN

Gambaran Umm Lokasi

Penelitian

Kota Sawahlunto merupakan bagian dari kota dalam propinsi Sumatera Barat yang terdiri dari 4 kecamatan, 37 desa atau kelurahan dan 9 kenagarian. Jumlah penduduk Kota Sawahlunto pada tahun 2004 yaitu 56,214 jiwa. Rumah sakit umum daerah (RSUD) Sawahlunto merupakan Rumah Sakit tpe C mitik pemerintah daerah Sawahlunto dengan SK Menteri Kesehatan No. 481/Menkes/SK/V/1997, dengan 5 (lima) pelayanan pokok, yaitu: pelayanan administrasi dan manajemen, pelayanan medis, pelayanan keperawatan, pelayanan gawat darurat dan pelayanan rekam medic dengan kapasitas tempat tidur sebanyak 71 tempat tidur. Tenaga keperawatan berdasarkan Data Kepegawaian tahun 2004 jumlah tenaga kerja perawat di instalasi rawat inap sebanyak 56 orang, kecuali perawat yang menjadi kepala di ruang rawat inap. Distribusi tenaga keperawatan berdasarkan tingkat pendidikan adalah D3 keperawatan 32 orang, D3 kebidanan 3 orang, D1 kebidanan 8 orang dan SPK 13 orang.

Pelaksanaan Penelitian 
Pelaksanaan penelitian dan proses pengumpulan data berlangsung dari tanggal 10 sampai dengan 23 Mei 2015. Pengumpulan data ini menggunakan instrument berupa angket yang dikumpulkan terhadap 56 responden yang kriterianya telah ditetapkan oleh peneliti.

1. Analisis Univariat

Berdasarkan hasil pengolahan dan analisis data terhadap variabel independen yaitu tingkat motivasi, tingkat imbalan, tingkat pendidikan, tingkat kepemimpinan dan variabel dependen yaitu tingkat kinerja perawat.Hasil analisis ini menggambarkan distribusi dari variabel-variabel yang diteliti Hasil analisis univariat ini dapat di sajikan dalam bentuk diagram dan narasi seperti berikut:

A. Tingkat

Motivasi, berdasarkan hasil analisis, separoh responden memiliki motivasi rendah yaitu $60,7 \%$.

B. Tingkat Imbalan, berdasarkan analisis, separoh responden menyatakan imbalan yang diterimanya kurang yaitu $71,4 \%$.

C. Tingkat Pendidikan, berdasarkan hasil analisis, separoh responden berpendidikan tinggi yaitu $62,5 \%$.

\section{Kepemimpinan,}

D. Tingkat berdasarkan hasil analisis,
separoh respnden menyatakan kepemimpinan kepala ruangan kurang baik yaitu $64,3 \%$.

E. Tingkat Kinerja, berdasarkan hasil analisis, separoh responden memiliki kinerja kurang baik yaitu 51,8\%.

2. Analisis Bivariat

Dari hasil analisis ini dapat ditihat hubungan antara dua variabel yaitu variabel independen dengan variabel dependen.Hasil analisis bivariate ini dapat disajikan adalah sebagai berikut.

A. Hubungan Tingkat Motivasi dengan Kinerja Perawat

Berdasarkan hasil analisis, bahwa proporsi kinerja responden kurang baik lebih besar pada motivasi rendah dibandingkan dengan motivasi tinggi $(64,7 \%$ : $31,8 \%$ ). Berdasarkan uji statistic perbedaan ini bermakna $\quad(p<0,05)$ Jadi terdapat hubungan antara motivasi dengan kinerja perawat.

B. Hubungan Tingkat Imbalan dengan Kinerja Perawat

Berdasarkan hasil analisis, bahwa proporsi kinerja responden kurang baik lebih besar pada imbalan kurang dibandingkan dengan imbalan cukup $(62,5 \%: 25,0 \%)$. Jadi terdapat hubungan antar imbalan dengan kinerja perawat.

C. Hubungan Tingkat Pendidikan dengan Kinerja Perawat

Berdasarkan hasil analisis, bahwa proporsi kinerja responden kurang baik lebih besar pada tingkat pendidikan menengah dibandingkan dengan tingkat pendidikan tinggi $(52,4 \%: 51,4 \%)$. 


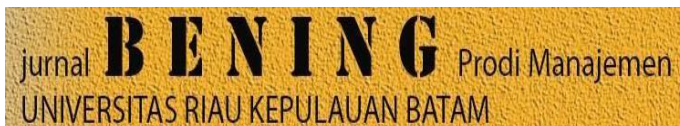

Berdasarkan uji statistic perbedaan ini tidak bermakna ( $p>0.05$ ).Jadi tidak terdapat hubungan antara tingkat pendidikan dengan kinerja perawat.

D. Hubungan Tingkat Kepemimpinan Kepala

Ruangan dengan Kinerja Perawat

Berdasarkan hasil analisis, bahwa proporsi kinerja responden kurang baik lebih besar pada kepemimpinan kepala ruangan kurang baik dibandingkan dengan kepemimpinan kepala ruangan $(63,9 \%: 30,0 \%)$. Berdasarkan uji statistic perbedaan ini bermakna $(\mathrm{p}<0,05)$. Jadi terdapat hubungan antara kepemimpinan kepala ruangan dengan kinerja perawat.

\section{Keterbatasan Penelitian}

Pada penelitian ini peneliti tidak melakukan uji angket terlebih dahulu, disebabkan oleh keterbatasan waktu dan biaya dalam peneliian. Keterbatasan hin adalah jumlah sampel yang kecil serta pertanyaan dalam angket kurang memadai baik dalam jumlah maupun variasinya.

\section{Analisis Univariat}

1. Gambaran Tingkat Motivasi
Perawat
Hasilpenelitian
gambaran bahwa lidapatkan
separoh perawat dari
motivasi rendah yaitu $60,7 \%$
dan perawat yang memiliki
motivasi tinggi 39,3\%.

Volume 5 No. 2 Tahun 2018

Penelitian yang dilakukan Ade Fauzi (2004) terhadap motivasi di RSUD Padanga Panjang, dimana didapatkan $47,7 \%$ perawat yang memiliki motivasi rendah.Pentingnya motivasi karena motivasi adalah yang menyebabkan menyalurkan dan mendukung perilaku manusia supaya mau bekerja gat serta antusia mencapai hasil yang optimal.

2. Gambaran Tingkat Imbalan Perawat

Hasil penelitian didapatkan gambaran bahwa lebih separoh perawat menyatakan imbalan yang diterimanya kurang yaitu $71,4 \%$ dan perawat menyatakan imbalan yang diterimanya kurang yaitu $71,4 \%$ dan perawat yang menyatakan imbalan yang diterimanya cukup yaitu $28,6 \%$. Hasil penelitian ini sesuai dengan penelitian yang dilakukan Ade Fauzi (2004) terhadap imbalan di RSUD Padang Panjang yang menunjukkan bahwa terdapat $51,1 \%$ perawat yang menyatakan imbalan yang diterimanya kurang.

3. Gambaran Tingkat Pendidikan Perawat

Hasil penelitian didapatkan gambaran bahwa lebih dari separoh perawat berpendidikan tinggi yaitu: $62,5 \%$ dan perawat yang berpendidikan menengah yaitu 37,5\%. Penelitian yang dilakukan oleh Amil (2003) terhadap tingkat pendidikan di RSUD Pariaman didapatkan bahwa hanya $40,9 \%$ perawat yang berpendidikan tinggi. 
4. Gambaran

Tingkat

Kepemimpinan Kepala Ruangan

Hasil penelitian didapatkan

bahwa lebih dari separoh perawat menyatakan

kepemimpinan kepala ruangan kurang baik yaitu $64,3 \%$ dan

perawat yang menyatakan kepemimpinan kepala ruangan baik yaitu $35,7 \%$. Hal ini sesuai dengan hasil penelitian yang dilakukan Ade Fauzi (2004) terhadap kepemimpinan kepala ruangan di RSUD Padang Panjang, dimana didapatkan $57,4 \%$ perawat yang menyatakan kepemimipinan kepala ruangan kurang baik.

5. Gambaran Tingkat kinerja perawat

Hasil penelirian didapatkan bahwa lebih dari separoh perawat memiliki kinerja kurang baik yaitu $51,8 \%$ dan perawat yang memiliki kinerja baik yaitu 48,2\%. Peneliian ini dilakukan Ade Fauzi (2004) terhadap kinerja perawat kurang baik yaitu $48,9 \%$.

Analisis Bivariat

1. Hubungan Tingkat Motivasi dengan Kinerja Perawat

Hasil penelifian menunjukkan bahwa proporsi kinerja perawat kurang baik lebih besar pada motivasi rendah dibandingkan dengan motivasi tinggi $(64,7 \%$ : $31,8 \%$ ). Berdasarkan uji statistic perbedaan ini bermakna $(\mathrm{p}<0,05)$. Jadi terdapat hubungan antara motivasi dengan kinerja perawat.Penelitian ini sesuai dengan hasil penelitian yang dilakukan Ade Fauzi (2004) terdapat motivasi di RSUD Padang Panjang yang membuktikan bahwa terdapat hubungan yang bermakna antara tingkat motivasi dengan kinerja perawat.

2. Hubungan Tingkat Imbalan dengan Kinerja Perawat

Hasil penelitian didapatkan bahwa proporsikinerja perawat kurang baik lebih besar pada imbalan kurang dibandingkan dengan imbalan cukup $(62,5 \%$ : $25,0 \%$ ). Berdasarkan uji statistik perbedaan ini bermakna ( $\mathrm{p}<05$ ).Jadi terdapat hubungan antara imbalan dengan kinerja perawat.Penelitian ini sesuai dengan hasil penelitian yang dilakukan Ade Fauzi (2004) terhadap imbalan di RSUD Padang Panjang yang membuktikan bahwa terdapat hubungan bermakna antara imbalan dengan kinerja perawat.

3. Hubungan Tingkat Pendidikan dengan Kinerja Perawat

Hasil penelitian menggambarkan bahwa proporsi kinerja perawat kurang baik lebih besar pada tingkat pendidikan menengah dibandingkan dengan tingkat pendidikan tinggi (52,4\%: $51,4 \%)$. Berdasarkan uji statistik perbedaan ini tidak bermakna $(\mathrm{p}>0,05)$. Jadi tidak terdapat hubungan antara tingkat pendidikan dengan kinerja perawat.Hal ini berarti bahwa tingkat pendidikan tidak mempengaruhi kinerja perawat.Penelitian ini sesuai dengan penelitian yang dilakukan Amil (2003) 


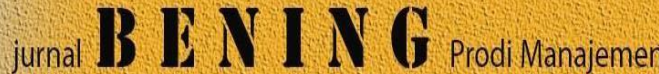 UNIVERSITAS RIAU KEPULAUAN BATAM}

terhadap tingkat pendidikan di RSUD Pariaman yang membuktikan bahwa tidak terdapat hubungan bermakna antara tingkat pendidikan dengan kinerja perawat.

4. Hubungan Kepemimpinan Kepala Ruangan dengan Kinerja Perawat

Hasil penelitian menunjukkan bahwa proporsi kinerja perawat kurang baik dibandingkan dengan kepemimpinan kepala ruangan baik (63,9\%: 30,0\%). Berdasarkan uji statistik perbedaan ini bermakna $(\mathrm{p}<0,05)$. Jadi terdapat hubungan antara kepemimpinan kepala ruangan dengan kinerja perawat.Penelitian ini sesuai dengan hasil penelitian yang dilakukan Yodrial (2004) terhadap kepemimpinan kepala ruangan di RSUD Batu Sangkar yang membuktikan bahwa terdapat hubungan bermakna antara kepemimpinan kepala ruangan dengan kinerja perawat.

\section{KESIMPULAN}

Berdasarkan uraian di atas, maka disimpulkan sebagai berikut. Lebih dari 50 persen perawat memiliki motivasi yang rendah, lebih dari separoh perawat menyatakan imbalan yang diterimanya kurang, lebih dari separoh perawat berpendidikan tinggi, lebih dari separoh menyatakan kepemimpinan kepala ruangan kuran baik, lebih dari separoh perawat memitiki kinerja yang kurang baik, terdapat hubungan antara motivasi dengan kinerja perawat, tidak terdapat hubungan antara tingkat pendidikan dengan kinerja perawat, terdapat hubungan
Volume 5 No. 2 Tahun 2018

antarakepemimpinan dengan kinerja perawat.

\section{SARAN}

Diharapkan kepada perawat perlu lebih meningkatkan motivasi dalam bekerja, diharapkan kepada pihak Rumah Sakit perlu lebih memperhatikan uang jasa/insentif perawat, diharapkan kepada kepala ruangan perlu lebih meningkatkan kegiatan pengarahan atau pergerakkan dan pengawasan kepada perawat pelaksana, perlu dilakukan penelitian lebih lanjut untuk menggali dan mengungkapkan masalahmasalah yang berhubungan dengan tingkat kinerja perawat lainnya.

\section{DAFTAR PUSTAKA}

Departemen Kesehatan RI. 2009. Pedoman Uraian Tugas Tenaga

Kerja Keperawatan di Rumah Sakit, Cetakan 2. Jakarta: Dirjen Yan. Med, 2009.

Darmayanti dan Ratnasari, Sri Langgeng.2016. Pengaruh Gaya Kepemimpinan Dan Fasilitas Kerja Terhadap Kinerja Pegawai Pada Kantor Camat Batam Kota.Zona Manajemen ISSN 2087-6998. Fakultas Ekonomi Universitas Batam Volume 8, Nomor 1, April 2016. Hal 11-18

Danur Mega Prativi, Ratri Wahyuningtyas. (2015). Pengaruh Lingkungan Kerja Fisik Terhadap Stres Kerja Karyawan PT Krakatau Steel Persero (Tbk) Divisi CRM. Journals of Management, 1-10.

Efendi, Vivi Kusuma dan Ratnasari, Sri Langgeng. 2014. Pengaruh Kepemimpinan, Komunikasi, Dan Motivasi Kerja Terhadap Kinerja 
Guru SMA Di Kecamatan Batam

Kota Batam Zona Manajemen

ISSN 2087-6998. Fakultas

Ekonomi Universitas Batam

Volume 6, Nomor 3, Desember

2014. Hal. 1-13

Fahmi, I. (2011). Manajemen Kepemimpinan (Teori dan Aplikasi). Bandung: Alfabeta.

Gibson L. James. 2007. Organisasi dan Manajemen Perilaku, Struktur, Proses.Jilid I. Terjemahan. Jakarta: Erangga.

Ilyas, Yaslis. Kinerja Teori, Penilaian dan Penelitian, penerbit pusat kajian Ekonomi Kesehatan. Depok: FKM UI.

I Made Bagus Indra Dewa, I Wayan Mudiartha Utama. (2014). Pengaruh Komunikasi , Kepemimpinan dan Lingkungan Kerja Terhadap Stres Kerja Pegawai pada PD . Pasar Kota Singaraja Unit Pasar Anyar. Journals of Managements, 45-62.

Kartono, K. (2015). Pemimpin dan Kepemimpinan. Jakarta: Rajawali Pers.

Kartono, K. (2016). Pemimpin dan Kepemimpinan. Jakarta: Rajagrafindo Persada.

Mulyadi, D. (2015). Perilaku Organisasi dan Kepemimpinan Layanan. Bandung: Alfabeta.

Lilo, Christianto dan Ratnasari, Sri Langgeng.2015. Pengaruh Gaya Kepemimpinan Dan Kompensasi Terhadap Kinerja Karyawan Pada PT. Supreme Nusapermai Development.Zona Manajerial. ISSN 2087-7331.Volume 7 Nomor 2, Agustus 2015.Hal. 5069. Fakultas Ekonomi Universitas Batam
Murwanto, Didik dan Ratnasari, Sri Langgeng.2016. Penganuh Kompensasi dan Gaya Kepemimpinan Terhadap Motivasi Kerja Karyawan PT. Fast Precision Manufacturing Indonesia.Zona Manajerial. ISSN 2087-7331. Volume 8 Nomor 1 , April 2016. Hal. 1-12. Fakultas Ekonomi Universitas Batam

Saputro, Andi dan Ratnasari, Sri Langgeng.2014. Penganuh Kepemimpinan dan Motivasi Kerja Terhadap Kinerja Karyawan PT. Giken Pricision Indonesia.Zona Manajerial ISSN 2087-7331. Volume 6 Nomor 3 , Desember 2014. Fakultas Ekonomi Universitas Batam Hal.112.

Sambas Ali Muhidin, Maman Abdurahman. (2007). Analisis Korelasi, Regresi dan Jalur. Bandung: CV Pustaka Setia.

Sanusi, A. (2011). Metodologi Penelitian Bisnis. Jakarta: Salemba Empat.

Sedarmayanti (2011). Tata Kerja dan Produktivitas Kerja. Bandung: CV Mandar Maju.

Sugiyono. (2014). Metode Penelitian Kuantitatif, Kualitatif dan $R \& D$. Bandung: Alfabeta.

Sujarweni, V. W. (2014). Metodologi Penelitian. Yogyakarta: PT Pustaka Baru.

Sunyoto, D. (2013). Perilaku Organisasional. Yogyakarta: Centre for Academic Publishing Service.

Sutrisno, E. (2009). Manajemen Sumber Daya Manusia. Jakarta: PrenadaMedia Group.

Veliana Sutanto, Jesslyn Angelina Mogi. (16). Analisa Pengaruh 
Work Family Confict Terhadap Stres Kerja dan Kinerja Karyawan di Restoran The Duck King Imperial Chef Gahxy Mall Surabaya. Journals of Management, 377-391.

Waluyo, M. (2012). Manajemen Psikologi Industri. Jakarta: Indeks.

Wasla, Elvina dan Ratnasari, Sri Langgeng.Pengaruh Gaya Kepemimpinan Dan Motivasi Terhadap Kinerja Karyawan PT. Citra Pembina Pengangkutan Industries Batam.EKSEKUTIF
Volume 5 No. 2 Tahun 2018

Jurnal Nasional Manajemen Bisnis Volume 13, Nomor 1, Juni 2016 ISSN: 1829-7501 Hal 97111

Wibowo, A. E. (2012). Aplikasi Praktis SPSS dalam Penelitian. Yogyakarta: Gava Media.

Zuhri, Haris. 2011. Hubungan Karakteristik Pasien Rawat Inap Dengan Tingkat Kepuasan Terhadap Layanan Keperawatan Serta Analisis Penyebab Ketidakpuasan Di Bagian Instalasi Rawat Inap RSUD Solok.Tesis. Jakarta: PSIKMUI. 